\title{
Fostering Entrepreneurship by Developing a New Learning Environment Within a Finnish University of Applied Sciences
}

\author{
Pasi Juvonen \\ Saimaa University of Applied Sciences, \\ Finland
}

\section{Introduction}

The rapidly escalating change requires new types of organizations, in which the continuous learning is seen as essential asset for organizations success (Marquardt 2002, 2009; Senge 1990, 2006; Easterby-Smith et al, 1999). The sooner the learners are familiar with ongoing change and the principle of lifelong learning the better they are able to succeed with their studies and their future career. Educators all over the world have to consider how to provide university students with appropriate skills that give them an opportunity to be successful during their studies and also after graduation. To be honest, no one exactly knows what will be the challenges we have to deal with in a couple of years. The need of new type of organizations, hot groups and innovative learning methods has been emphasized also in management and business literature (c.f. Lipman-Blumen \& Leavitt 1999; Hamel \& Green 2007; Marquardt 2009).

Instead of only transferring existing information to the students, we should create learning environments where the students will want to take own responsibility for their learning by themselves by creating knowledge via shared practice. Furthermore students can build their self confidence by taking risks in within an environment where there will be no real financial loss in case of failure. Within these learning environments learning will take place by methods the learners will find useful, within a cooperative which they own by themselves, or within a project group. In both cases, the students study theory by reading books and apply the knowledge by carrying out projects for customer companies. Studying is supported by teachers who act as mentors and coaches. Learning by doing is emphasized in these kinds of learning environments. The teachers' role and responsibility will be in this kind of learning environment to facilitate learning by maintaining and further developing the learning environment.

This article will present how a learning environment that fosters entrepreneurship is being created for Information Technology (IT) Bachelor education in Saimaa University of Applied Sciences (SUAS). The study has been started in February 2010 and it will continue until December 2013. There are no final results available at this stage, however, some observations related to learning experiences of students utilizing team learning methods can already be shared. The study will also suggest that entrepreneurship can be supported by 
developing a learning environment where students can select learning with the methods that they feel appropriate for themselves.

\subsection{Motivation for the study}

The primary objective for developing the learning environment has been to better prepare the IT bachelor students for challenges of ongoing change that they will meet during their future careers. Lenses used for the study are:

How could we foster entrepreneurship by developing learning environment for IT Bachelor education?

This will also serve as a research question.

The Finnish Ministry of Education and Culture (former Finnish Ministry of Education) has set the objectives for supporting entrepreneurship in Finnish Universities at national level (Ministry of Education 2003; 2004; 2009). The author has translated the objectives based on the original Finnish materials. A summary of the objectives set by the Ministry of Education and Culture is presented here:

- University level entrepreneurship is encouraged by integrating entrepreneurship broadly to studies at Universities of Applied Sciences. (Ministry of Education 2004,p. 23)

- The Universities of Applied Sciences will act as cooperation coordinators between students and working life and will see to that cooperation will be systematically deepened during university studies (Ministry of Education, 2008, p. 50)

- Promotion of internal and external entrepreneurship, the creation of new business, and innovation. (Ministry of Education 2009, p. 14)

- Creation of an entrepreneurship culture and a mindset and climate conducive to entrepreneurship. (Ministry of Education 2009, p. 14)

To define "entrepreneurship" the following definition by European Commission is used:

“Entrepreneurship refers to an individual's ability to turn ideas into action. It includes creativity, innovation and risk taking, as well as the ability to plan and manage projects in order to achieve objectives. This supports everyone in day to day life at home and in society, employees in being aware of the context of their work and being able to seize opportunities, and is a foundation for more specific skills and knowledge needed by entrepreneurs establishing social or commercial activity." (COMMISSION OF THE EUROPEAN COMMUNITIES, 2005, emphasis added by the author).

So far the effects of the tools and methods with the new learning environment have been only discussed on practical level. They have not yet been analyzed from the viewpoint of entrepreneurship based on any theoretical framework. Now the definition of entrepreneurship by Commission of the European Communities and the objectives set by Ministry of Education and Culture are used as the framework to discuss the benefits of the learning environment created for IT Bachelor education.

\section{Background}

This chapter will shortly present the theories on which understanding of a proper current and future learning environment is based. The theories presented here have something in 
common. They all see an individual as a social being and learning as a social and communal phenomenon. They also see learners as active subjects (rather than passive objects who need to be taught) who will take responsibility for their own learning process when they have an opportunity to do it. These theories consist of Experimental Learning by David Kolb, Social learning theory by Etienne Wenger, Knowledge theory by Ikujiro Nonaka and Hirotaka Takeuchi, theory of learning organization by Peter M. Senge and associates, principles of Organizational learning by Chris Argyris and Donald A. Schön and Action learning theory by Michael J. Marquardt. These theories are presented and discussed below.

\subsection{Social learning theory}

Etienne Wenger argues that learning is a social participation (Wenger, 1998). It consists of meaning (learning as experience), identity (learning as becoming), practice (learning as doing) and community (learning as belonging). Brown and Duguid define communities of practice $(\mathrm{CoP})$ as social constructs of individuals that connect together people sharing the same interests, objectives - even beliefs and values (Brown and Duguid 1991). They argue that CoPs explain how shared learning is entrenched in complex collaborating environment. The social theory of learning, presented by Wenger combines all the structures presented above. All these social constructs are made in a way that they enable learning in a more efficient way (Wenger 1998).

By creating appropriate circumstances communities of practice may emerge, develop and flourish. By allowing peripheral participation (Lave \& Wenger, 1991), learners may slowly move from peripherality to full membership of CoP. The peripherality could be compared to pre-industrial communities where newcomers of a practice where first apprentices and finally became masters of that practice. IT Bachelor students in our degree programme study usually four years before graduate. During this time most of them they will move from peripheral participation to full membership of being IT bachelor student or being a team entrepreneur.

\subsection{Knowledge theory}

The knowledge has been separated into explicit knowledge and tacit knowledge. Explicit knowledge can be learned from books or other similar sources. Tacit knowledge can be expanded through an individual's experiences. Nonaka defines knowledge creation as a spiraling process between explicit and tacit knowledge. This interaction will create new knowledge. Nonaka goes on by arguing that organizational knowledge is created through a continuous dialogue between tacit and explicit knowledge. Four patterns of interactions, socialization (sharing and creating tacit knowledge through direct experience), combination (combing explicit knowledge with help of information systems), internalization (converting explicit knowledge to tacit knowledge through practice) and externalization (converting tacit knowledge to explicit knowledge trough dialogue and reflection) are used to implement organizational knowledge creation. These stages are nowadays well known as the SECI process (Nonaka 1994; Nonaka \& Takeuchi 1995; Nonaka \& Toyama 2003; Von Krogh et al. 2000). 


\subsection{Experimental learning}

The SECI process presented above has much in common with the model presented by David Kolb a decade earlier. Kolb's work is based on John Dewey's and Kurt Lewin's studies, those who highlighted the role of democratic values like cooperative leadership and dialogue in experimental learning (Kolb 1984, 17). Kolb defines experimental learning as a "central process of human adaptation to the social and physical environment." (Kolb 1984, 31). The process of experimental learning has four structural dimensions: 1) Active experimentation 2) Divergent knowledge 3) Reflective observation 4) Abstract conceptualization. Each of these dimensions will generate different type of knowledge and they all are necessary to a learner (Kolb 1984, 42).

Kolb defines affectively complex learning environments as "ones in which the emphasis is on experiencing what is actually like to be a professional in the field under study. Learners are engaged in activities that simulate or mirror what they would do as graduates, or they are courage to reflect upon an experience to generate these insides and feelings. The information discussed and generated is more often current / immediate. It often comes from expressions of feelings, values and opinions by the learner in discussions with peers or the teacher. Such expressions of feelings are encouraged and seen as productive inputs to the learning process. The learner's activities often vary from any prior schedule as a result of the learner's needs. The teacher serves as a role model for the field of profession, relating to learners on a personal basis and more often as a colleague than an authority. Feedback is personalized with regard to each individual's needs and goals, as opposed to comparative. It can come from both peers and the teacher. There is accepted discussion and critique of how the course is proceeding, and thus, specific events within a single class session are often more emergent than prescribed" (Kolb 1984, p. 198). Other types of learning environments are 2) Perceptually complex learning environment where multiple methods are preferred and process of doing is emphasized rather that outcome. 3) Symbolically complex learning environment where students are trying to solve a problem for which there is a right answer or a best solution. 4) Behaviorally complex learning environments are those in which the emphasis is upon actively applying knowledge or skills to a practical problem.

Kolb's thoughts of an affectively complex learning environment have been in this study applied into practice with IT Bachelor education and expanded from the level of single academic course to whole the curriculum of IT Bachelor students. The learning environment that has been created also utilizes the ideas of a perceptually complex learning environment and a behaviorally complex learning environment. The ideas of symbolically complex learning environment have not been emphasized.

\subsection{Studies on learning organization}

The concept of learning organization has been presented to wider audience by Peter M. Senge. In his studies of learning organization (cf. Senge 1990, 2006; Senge at al 1994, 1999, 2000), Senge presents five disciplines with help of which a learning organization could be created. These five disciplines are: 1) Systems thinking 2) Personal Mastery 3) Mental models 4) Building shared vision 5) Team learning.

Systems thinking has been defined as an ability to see invisible fabrics, patterns of behavior and connections between interrelated actions. It is the ability to see the conceptual 
framework of "what is happening?" and it is not easy to recognize the system if one is part of the system that he wants to analyze and understand. Personal mastery means that an individual is committed to become better in whatever he is committed to do in his professional life. With support from one's organization an individual commits to his personal lifelong learning. Mental models are everyone's hidden assumptions that affect to how we think and act; and one way to diminish their effect is trying to make them visible. To be able to develop as individuals and as a team, everyone should share one's ingrained assumptions, generalizations and other phenomena that affect to our way of understanding the world and our actions as part of it. Building a shared vision deals with "picture of the future", where the team or group wants to go. Shared vision cannot be a vision that some individual has, it is rather build up from personal visions melted together in course of time and with shared practice between individuals. Team learning is crucial because a team has for a long time been the basic unit of learning.

Team learning deals with patterns of defensiveness in human beings and tries to lift selfdefence patterns up to the surface to eliminate them. This will require time and patience. In a longer run mutual trust may develop between team members if they will commit themselves to the process. By practicing dialogue it is in a longer run possible for normal people to achieve extra-ordinary results by really thinking together (Senge 1990; Isaacs 1999).

The learning organization combines people, technology, organization and knowledge with learning. Due to ongoing change caused by globalization only organizations which will succeed in combining these elements will sustain (Marquardt 2002).

\subsection{Organizational learning defined}

Organizations are seen as collectivities that in ideal situation learn when their members learn. (Argyris and Schön 1996, 6-7) When learning organization theorists like Peter M. Senge with his associates and Micheal J. Marquardt describe an ideal organization, its characteristics and means how it could be created, theories of organizational learning mostly deal with human defensive reasoning and the ways of overcoming it with planned interventions (Argyris and Schön, 1996, 150-176). Argyris has also been first author to make concepts single-loop and double-loop learning famous for wider public. Single-loop learning means that we learn to make current operations more effectively without questioning the governing variables underlying the operations. Double-loop learning instead concentrates to questioning the underlying beliefs and values and asks if we are doing right things or not.

Furthermore, according to Argyris and Schön argue that there is a difference what individuals say what they are doing (espoused theory) differs from what they actually do in practice (theory-in-action). Without noticing this difference individuals tend to make decisions based on their espoused theories (Argyris and Schön 1996, 13-15). When Senge and other learning organization authors discuss mental models, they mostly refer to Argyris' work on humans' habit of defensive reasoning. Argyris and Schön have also studied the use of dialogue; and their work has been further developed by William Isaacs (Isaacs, 1999) who's outsanding book on dialogue also combines the theories presented within this article. 
Another well known author on organizational learning is Nancy Dixon. She introduced three types of meaning structures among organizations members. These structures are: private, accessible and collective. The flexibility of boundaries between these meaning structures has an influence to organizations ability to learn (Dixon 1984, 36-43). By moving these boundaries with proper interventions and collective learning methods the share of collective meaning could be expanded.

\subsection{Action learning}

The concept of action learning has been recently emphasized by Micheal J. Marquardt. There have been several variations of the concept but they all share some common elements. The action learning requires real people solving real problems in real time and learning while doing so.

Action learning method consists of six components: 1) Problem 2) Group 3) Questions 4) Action 5) Learning 6) Coach. The problem should be significant and urgent and it should be the responsibility of the team (group) to solve it (Marquardt 2009, 2-3). Asking right questions rather than providing answers is essential in action learning. This will help individuals to separate what they don't already know. Asking questions is also seen as an instrument of a good leader (Marquardt 2009, 74). Asking questions and planning responses to them develops the individuals' ability to reflective inquiry. If learning is not intervened by questions, reflection of what has been learned is easily overshadowed by the urgency of the problem itself (Marquardt 2009, 137 - 140). This suggests that the coach should now and then make an intervention to problem solving for the sake of learning even in situations where everything seems to be running smoothly. Maybe the intervention should be done especially in those situations?

Action learning is seen as a continuous process where the phases follow each other. From this viewpoint the methods overlaps with Kolb's experimental learning cycle, Nonaka's knowledge theory and team learning cycle by Senge et al. Action learning also overlap with some other widely used learning methods, such problem based learning, project learning and learning by development. All of these methods are based on real problems, teamwork, and learning as a social and communal phenomenon. They all also utilize learning by doing as main source of knowledge and combine theories and best practices from several disciplines, such as group dynamics, management science, and psychology and pedagogy.

\subsection{Pedagogical fundamentals for the school of future}

Pedagogical background for the school of future will be based on learning as social and communal process, teaching as facilitating this process and knowledge as a fuel and also as a product of the learning process. The basis for the future school is presented in figure 1.

The fundamentals presented in figure 1 are based on the studies made in elementary school (Smeds et al. 2010) but they are also applicable to university level education. Smeds et al. have summarized several theories that exist behind the development of new kinds of learning environments. 


\subsection{Summary of the background}

Why to put effort on presenting the theoretical background related to learning? The answer is that the theoretical background presented here lies behind the most team learning methods commonly used in education. Any theory presented in the previous chapters would deserve much closer look and discussion. Fortunately there are plenty of textbooks available on any of the topics.

\begin{tabular}{|l|l|l|}
\hline Theme & Author(s) & Key assumption(s) \\
\hline $\begin{array}{l}\text { Social learning } \\
\text { theory }\end{array}$ & $\begin{array}{l}\text { Lave \& Wenger } \\
\text { 1991; Wenger, } \\
1998 .\end{array}$ & $\begin{array}{l}\text { Learning is a social and a context related process. } \\
\text { Knowledge is always situated. Human beings learn } \\
\text { from peers via shared practice and by observing } \\
\text { masters. }\end{array}$ \\
\hline $\begin{array}{l}\text { The knowledge } \\
\text { theory }\end{array}$ & $\begin{array}{l}\text { Nonaka, 1994; } \\
\text { Nonaka \& } \\
\text { Takeuchi 1995; } \\
\text { Nonaka \& } \\
\text { Toyama 2003. }\end{array}$ & $\begin{array}{l}\text { Tacit knowledge is created and transferred through } \\
\text { shared practice and codified with a dialogue and } \\
\text { reflection. Codified knowledge will be again utilized } \\
\text { into practice by utilizing information systems. By } \\
\text { following this process the total amount of } \\
\text { organizational knowledge can be expanded. }\end{array}$ \\
\hline $\begin{array}{l}\text { Experimental } \\
\text { learning }\end{array}$ & Kolb, 1984. & $\begin{array}{l}\text { A learning process includes various stages where } \\
\text { different kinds of approaches for learning are } \\
\text { required. }\end{array}$ \\
\hline $\begin{array}{l}\text { Learning } \\
\text { organization }\end{array}$ & $\begin{array}{l}\text { Senge, 1990, 1996; } \\
\text { Senge et al. 1994, } \\
\text { Marquardt, 2002: } 2000 ;\end{array}$ & $\begin{array}{l}\text { A learning organization is built from various } \\
\text { elements, such as team learning and shared vision. } \\
\text { The learning organization combines people, } \\
\text { technology, organization and knowledge with } \\
\text { learning. }\end{array}$ \\
\hline $\begin{array}{l}\text { Organizational } \\
\text { learning }\end{array}$ & $\begin{array}{l}\text { Argyris \& Schön } \\
1996 ; \text { Dixon 1984. }\end{array}$ & $\begin{array}{l}\text { Learning within organizations could be made more } \\
\text { productive by increased communication (dialogue) } \\
\text { and surfacing hidden mental models to diminish } \\
\text { human defensive reasoning. Increased } \\
\text { communication will also help to diminish ambiguity } \\
\text { related to learning of individuals within the } \\
\text { organizations. Learning process in organizations } \\
\text { should be supported by planned interventions made } \\
\text { by researchers or consultants. }\end{array}$ \\
\hline future & Marquardt 2009. & $\begin{array}{l}\text { Learning takes place through solving real problems } \\
\text { in real environment within a team supported by a } \\
\text { coach. Asking questions and reflecting of the learnt } \\
\text { are essential. }\end{array}$ \\
\hline Smearning for
\end{tabular}

Table 1. A summary of the theoretical background related to guiding ideas behind the development of the learning environment. 


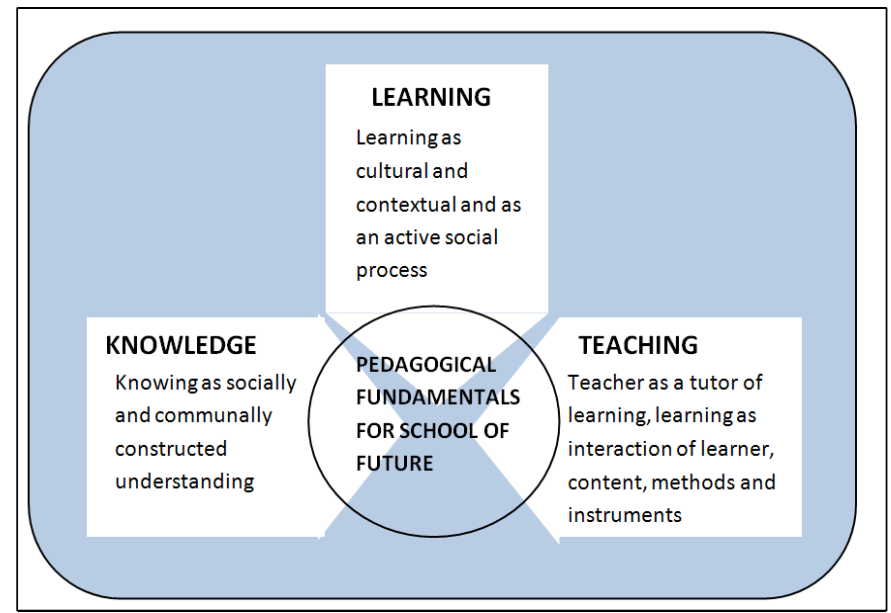

Fig. 1. Pedagogical fundamentals for school of future (modified from Smeds et al. 2010).

There are lots of whole disciplines of research such as organizational psychology, group dynamics, motivation theories and pedagogy which are more or less related to the subject of this study, but they are not presented here. The authors' goal was to clarify the theoretical background behind the learning environment that has been created and also to illustrate the multi-faceted environment where university level IT Bachelor education nowadays operates. A short summary of the theoretical background related to guiding ideas behind development of the learning environment is presented in table 1.

\section{The research process}

This chapter will describe how the research is being conducted. It will also clarify the methods used both in data collection and data analysis.

\subsection{Methods of data collection}

The students studying IT in our degree programme are divided into four different groups from the viewpoint of this study. These groups are IT team entrepreneurs (teampreneurs), members of the game team, students studying within the international team learning path, and students studying within the project learning path (in more detail, see figure 3 ).

Data for the article was collected between April 2010 and September 2011 and it consisted of theme-based interviews, observation of team learning sessions "trainings" and analysis of documents in the information repository used by teampreneurs and their coach. The teampreneurs were interviewed first time in April 2010 and second time in February 2011, and total of 25 theme-based interviews were carried out. Interviews lasted from 30 to 120 minutes. To be able to verify how interviewees express their arguments and emotions in team learning sessions, a total of 22 team learning sessions were observed between May 2010 and September 2011. These team learning sessions lasted from 2 to 8 hours. In addition, the author has observed two so-called kickstart events where the teampreneurs were negotiating their leading thoughts, values and mission. Both of these events lasted for two days. 
The author had also access to information repository used by teampreneurs and could follow both the written documentation made by teampreneurs and their coach. Both the coaches of the two IT cooperatives and the author are working as lecturers in IT Bachelor degree programme so there have all the time been possibilities to validate in this way the interpretations with the coaches. Some of the questions asked from the teampreneurs during the theme-based interviews were also discussed later in trainings and other team learning situations by teampreneurs themselves. The author has also been able to have access to the students' transcript of records, in order to find out how the studies for IT Bachelor degree are progressing.

The members of the game team were interviewed twice. The first interview was carried out in October 2010 and the second in April 2011. The members of the game team wanted to be interviewed as a team, and therefore both interviews were carried out as group interviews. The interviews were theme-based with some predefined general level themes. Discussions with the coach of the game team has been a secondary source of data.

Students who study within the international group have had development discussions with their tutoring teacher once a year. The author of the article has been the tutoring teacher for the international groups since 2009 and this way the author has been able to interview also these students regularly. We have also organized feedback dialogues twice a term for the international group. These events have also been a fruitful source of data. In addition, the author is involved in planning and organizing education for the international groups. Discussions and email conversations with other colleagues who are involved in organizing courses for the international group, have offered a secondary source of data.

The students who have chosen the project learning study path have been investigated mostly by development discussions. Discussions and weekly dialogues with colleagues have served as a secondary source of data. The author has also had access to students' transcription of records on the basis of which some evaluation of overall progress of studies could be made.

\section{Summary of data collection}

Observing the students who have chosen the ICT entrepreneurship study path has been emphasized in data collection. The decision was made because this study path was seen as a remarkably different compared to the other two paths (international team learning and project learning). It was also estimated that with the ICT entrepreneur study path we would face also so far unknown challenges and would be able to learn from solving those challenges. Therefore it was seen as a rich target for closer investigation.

\subsection{Methods for data analysis}

The interviews were first transcribed to ASCII text and then analyzed utilizing grounded theory (Strauss \& Corbin 1990; Corbin \& Strauss 2008) and case study (Yin 2003; Flick 2009) methods. The field notes during the observation of trainings and other team learning sessions were written to files and complemented with a research diary with memos of the researcher's comments, questions and drafts of analysis. 
Based on Flick qualitative research is of specific relevance to the study of social relations (Flick 2009, 12). For this study qualitative methods were selected because they help to build a richer description of the phenomena studied. For qualitative studies it is typical that multiple methods are used in order to gain more validity for the study.

The grounded theory analysis started with an open coding phase. The open coding phase was based on certain seed categories that in other words meant an interesting phenomenon related to selected research questions. The original seed categories for the analysis were: learning experiences, future challenges, risk taking and team development. Based on the methodological instructions which are related to grounded theory method, the data collection should be continued at least until the data is theoretically saturated (Corbin \& Strauss 2008, 263). In other words, when the same phenomena start to repeat themselves in the extra interviews made, there is no reason to continue data collection for that category. After eleven theme-based interviews all the seed categories were well saturated and it became evident that the future challenges and risk taking seed categories were very close to each other.

Open coding was followed by an axial coding phase, which in practice went on almost in parallel with the open coding phase. During axial coding the observations were grouped and relations between them were analyzed. During the open coding and axial coding phases theoretical sampling (Denzin \& Lincoln 2003; Corbin \& Strauss 2008) was used (both with interviews and observation) to get better understanding of the interesting phenomena and their relations that were expressed by teampreneurs. Theoretical sampling based on the data with original seed categories guided further data collection. Two new seed categories, shared goals and working approach, and handling of crisis situations were established based on the theoretical sampling.

The last phase of the analysis was a selective coding. In selective coding the core of the results was formed, and "a story of the case" (Flick 2008) was written. In other words after the selective coding it was possible to say what was going on with the students who are studying IT bachelor degree within the learning environment. A summary of the research methods used in the study is presented in table 2.

Critical incident technology (CIT) is a qualitative analysis method that helps researcher to dig in to critical positive and negative incidents that interviewees have experienced based on their own expressions (Symon \& Cassell 1998). With CIT it will be possible to capture the most (i.e. $5-10 \%$ ) critical positive and negative that have happened and possibly separate them for further analysis. By especially concentrating to critical incidents CIT might also provide an interviewee a possibility to reflect personal development and learning experiences as a team member. CIT was used during the theme-based interviews to help the interviewees to recall and reflect on their learning experiences, and it turned out to be a useful method for the ongoing study and it provided a richness of useful insights for further data collection.

The study has been a cyclic process, where data collection, data analysis, planning actions, and implementing the actions into practice, are all repeating themselves. The length of a cycle has so far varied from a few weeks to several months depending on themes under investigation. The study follows the structure typical for action research (Herr \& Anderson, 
2005; Stringer 2007). Furthermore, there are several parallel processes such as individual learning, team learning and performance measures of the cooperative going on with several groups of students. Therefore several cyclic processes are running in parallel within the study.

\begin{tabular}{|l|l|l|}
\hline Method & A short description & Reference(s) \\
\hline $\begin{array}{l}\text { Action } \\
\text { Research }\end{array}$ & $\begin{array}{l}\text { Action research examines the phenomena in their natural } \\
\text { settings. Action research as a method has emerged from } \\
\text { different traditions and covers several different approaches, } \\
\text { i.e. practioners research, action science, participatory rural } \\
\text { appraisal, teacher research, participatory action research and } \\
\text { feminist participatory action research. }\end{array}$ & $\begin{array}{l}\text { Herr \& } \\
\text { Anderson, 2005. }\end{array}$ \\
\hline Case study & $\begin{array}{l}\text { Case study is an empirical inquiry that investigates a } \\
\text { phenomenon within its real-life context. Case study research } \\
\text { means single and / or multiple case studies, that can include } \\
\text { either quantitative or qualitative evidence, even both. It } \\
\text { usually relies on multiple sources of evidence and benefits } \\
\text { from the prior development of theories. }\end{array}$ & $\begin{array}{l}\text { Eisenhardt 1989; } \\
\text { Graebner (2007); } \\
\text { Yin 1994, 2003. }\end{array}$ \\
\hline $\begin{array}{l}\text { Grounded } \\
\text { theory }\end{array}$ & $\begin{array}{l}\text { Grounded theory is a research method that has its origins in } \\
\text { social sciences. Grounded theory is an inductive research } \\
\text { method where the research starts with almost no a priori } \\
\text { knowledge about the subject studied. The theory emerges } \\
\text { from the data during the data is being analyzed. }\end{array}$ & $\begin{array}{l}\text { Strauss, A. \& } \\
\text { Corbin, J. 1990; } \\
\text { Corbin \& } \\
\text { Strauss, 2008. }\end{array}$ \\
\hline
\end{tabular}

Table 2. Summary of the research methods used in the study (modified from Juvonen \& Ovaska, 2010)

\section{Summary of data analysis}

In general this study is a typical exploratory case study where construct validity is achieved through the use of multiple sources of evidence. The use of multiple sources of evidence is called data triangulation (Flick 2009, 444). The author being the only researcher in the study no official investigator triangulation was used (Flick 2009, 445). However, the author has worked in close cooperation with coaches of the two IT cooperatives, this has offered possibilities for tens of unofficial discussions related to the subjects under investigation. The study will get more internal validity. This will be in a longer run achieved by comparisons of student groups studying within different study paths of the learning environment.

\section{Description of the learning environment}

The theoretical background of learning as a social phenomenon and knowledge as product of cooperation was discussed in previous chapters. This chapter aims to clarify how these thoughts have been taken into practice by planning and implementing a learning environment with IT Bachelor education in SUAS. Firstly, the objectives for learning environment that would support entrepreneurship set by Finnish Ministry of Education and Culture are presented. After that, the structure behind the realization of the learning environment is presented. Thirdly, some examples of team learning methods used within the learning environment are presented. 


\subsection{Objectives for the learning environment that would support entrepreneurship}

The Ministry of Education and Culture has defined a set of criteria for learning environment which will support entrepreneurship. The criteria are as follows:

- “Student's own activity is emphasized

- Learning takes place also in simulated or real-life situations

- Students have a possibility to interact with real entrepreneurship

- Learning is based on problem solving and interaction

- Learners are supported by a network of specialists

- The teachers role develops from delivering information to organizing, tutoring, supervising and developing the learning environment" (Ministry of Education, 2009, translated by author)

The first realization based on authors' current knowledge of learning environment that is based on the theories presented above in university level education was carried out by the Tiimiakatemia. The Tiimiakatemia started with marketing education in 1993 and nowadays it's a unit of education that is specialized in entrepreneurship. Its objectives are to develop individual and team abilities in three areas: team entrepreneurship (teampreneurship), team learning, and team leadership (Partus methods).

Our one of the learning environment applies and further develops the solution originally developed in the Tiimiakatemia to IT Bachelor education. Based on the author's current best knowledge (and a literature study made in April 2011) any similar learning environment has not been implemented in practice with IT Bachelor education before our realization.

Learning environments will in future combine teaching, learning and knowledge. Teaching is no longer seen purely as transmission where teacher tries to transfer existing knowledge to students. Teachers will rather act as tutors or coaches who facilitate how learners utilize each other and the instruments of the learning environment. The other role of teachers' is to actively and continuously experiment and develop methods and instruments used in community and team learning.

\subsection{The overall structure of our realization of the learning environment}

All students in the IT degree programme in SUAS have identical curricula during their first year of study. They will have courses in subjects like basic Information and Communications Technology (ICT) skills, mathematics, physics, languages and methods for learning. During their first spring semester they will decide how they want to continue their studies after the first year. The overall structure of the curriculum and the study paths in our IT degree program are presented in figure 2.

Those who choose the international team learning study path will study in English with international exchange students coming from several countries such as Czech Republic, Russia and China. This group that we call InnoSet, utilizes team-learning methods in international environment and works in teams by doing projects for local companies and other organizations. The tasks they perform usually require complex inquiry to existing knowledge with multiple methods. The projects are steered in cooperation with teachers of SUAS and representatives from cooperation organizations. 
The Finnish students who study within this InnoSet group usually choose to study their third year abroad in one of our cooperation Universities. Most of them will also do their practical training (30 ECTS points) during their exchange period. For the fourth year the students will come back to SUAS to finish their studies and to write their Bachelor Thesis.

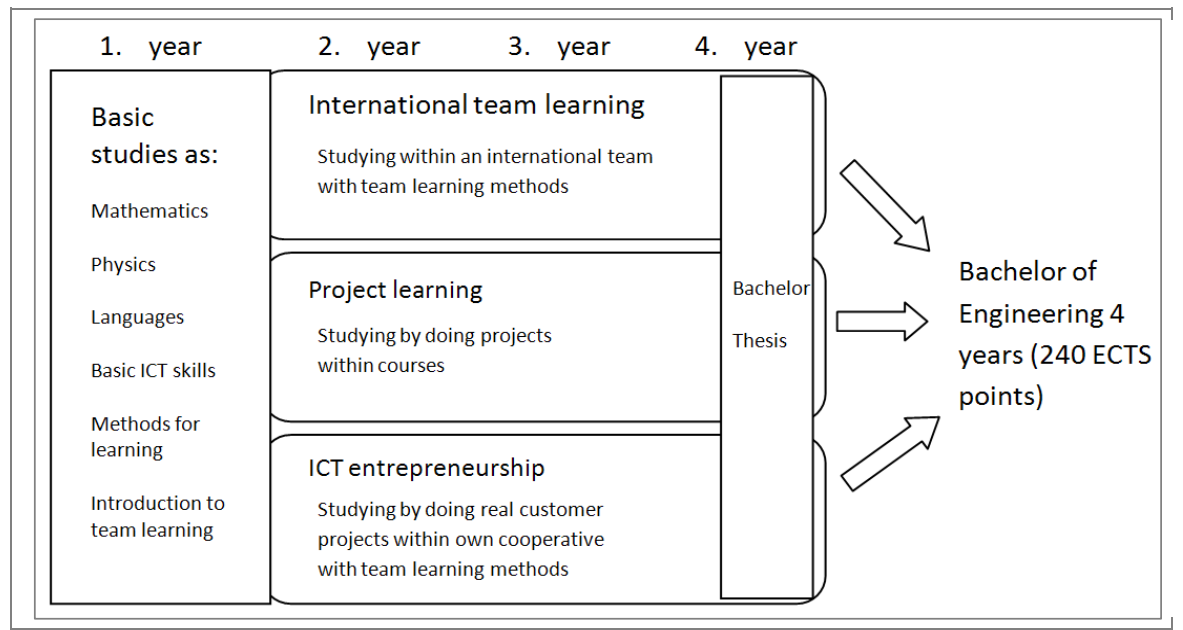

Fig. 2. The overall structure and the study paths of the curriculum in Information Technology degree programme in SUAS.

Students who study 60 ECTS points abroad at our cooperation university will get a Double Degree (DD) when they graduate. In practice they will get a bachelor's diploma both from the SUAS and the cooperation university.

Students who will decide to study by participating to courses and carrying out projects within the courses usually select the project learning study path. The students will have more conventional courses and the projects are included in the courses. In this way, learning by doing is emphasized here too. Students are also encouraged to find projects themselves. The projects are steered in cooperation with the teachers of SUAS and representatives from the cooperation organizations.

In case the students choose to continue their studies as ICT entrepreneurs, they will establish an IT cooperative in the end of their first academic year and start operating the cooperative in the beginning of their second academic year. They will then run the operations of their cooperative for three years until they graduate. We call these students teampreneurs.

There is also a so-called game team, which is a group of four students who study for their Bachelor's degree by designing and deploying games for PC computer and portable devices. The game team could be described as a special case of ICT entrepreneurship. The students of the game team will also establish a company to be able to sell their products. The game team has a coach, who reflects the learning experiences with the team and inspires them with their studies. The overall setting for the study and the authors' role in it is described in figure 3. 


\subsection{A cooperative as a structure for organizing and as a vehicle of team learning and team development}

First IT cooperative in Saimaa University of Applied Sciences, Icaros, was established in 2010 and it is 100 percent owned by nine IT degree programme students of Saimaa University of Applied Sciences (SUAS). The cooperative helps students to organize their actions, mitigate the risk as being an entrepreneur and deal with money gained from the customer projects. Above of these basic practical issues, the cooperative acts as a vehicle for team learning. The team learning methods provide a practice-oriented way to study IT in SUAS. The methods used in team learning are based on research related to learning organization, team building and development, organizational knowledge creation and knowledge sharing. During the autumn 2011 the second IT cooperative, Ideatech, was established and it started operating in September 2011.

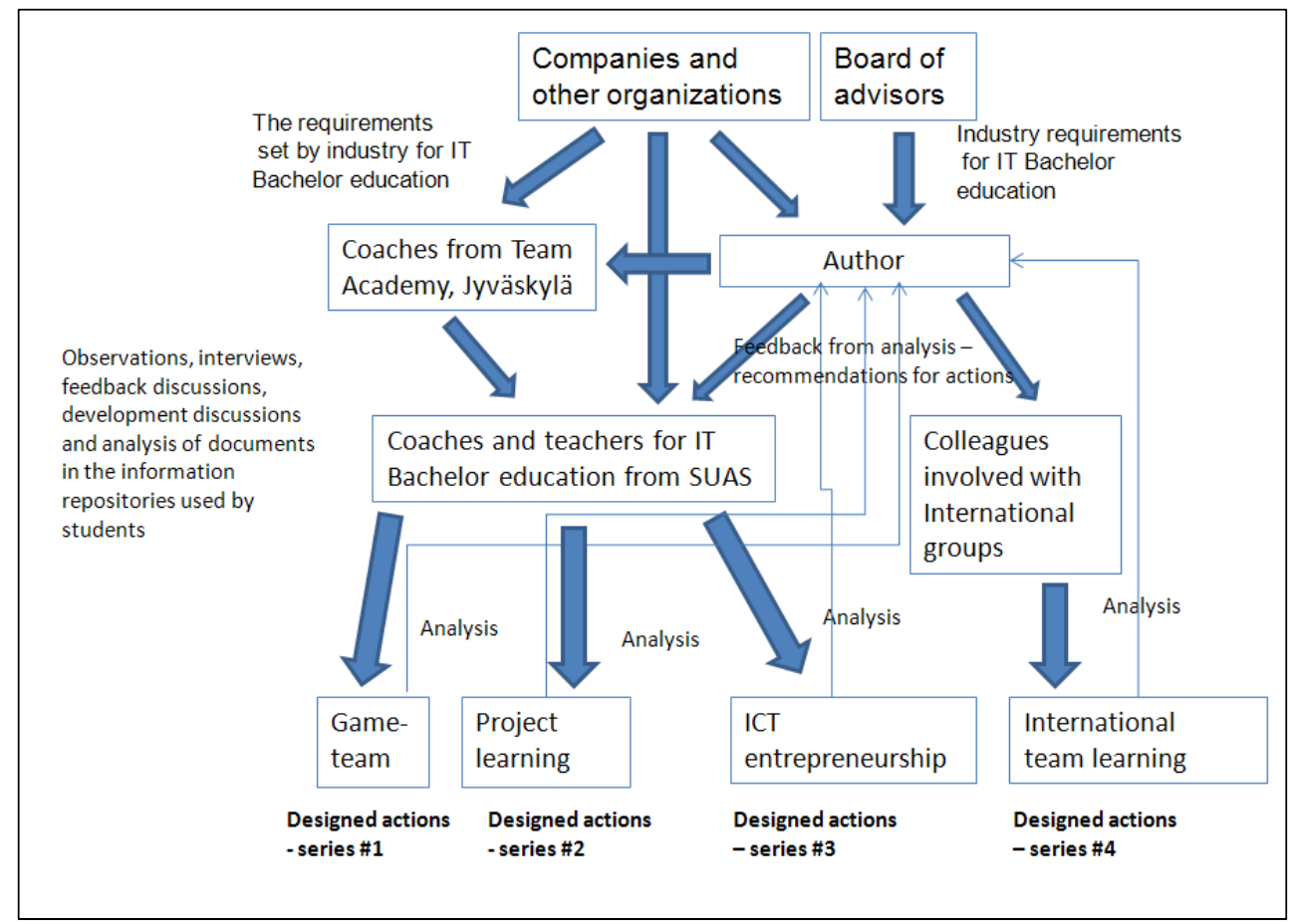

Fig. 3. A description of the overall setting for the study.

\subsection{Examples of used methods within our learning environment}

There are plenty of tools and methods for individual and team learning and for creating new ideas and developing them to innovations. Within the study paths new methods are also explored now and then by combining the existing ones. Most of these methods are based on the literature that was previously discussed and many of them have a number of versions. The most commonly used team learning methods are shortly presented in table 3 . 


\begin{tabular}{|c|c|c|}
\hline $\begin{array}{l}\text { Name (that we } \\
\text { are using) }\end{array}$ & A short description & $\begin{array}{l}\text { Background/ } \\
\text { Reference(s) }\end{array}$ \\
\hline Team role test & $\begin{array}{l}\text { Team role test by Belbin is made for students in } \\
\text { the beginning of their first year and again for } \\
\text { those who choose to continue their studies ICT } \\
\text { entrepreneurs in the end of first year. The results } \\
\text { of the test are used later to help students to reflect } \\
\text { on themselves as team workers. }\end{array}$ & Belbin, 2003. \\
\hline $\begin{array}{l}\text { Tryouts / } \\
\text { Trainings / } \\
\text { Retreats }\end{array}$ & $\begin{array}{l}\text { Students share information about their learning } \\
\text { experiences in team learning sessions twice a week. } \\
\text { These sessions usually last for } 3-4 \text { hours. Retreats } \\
\text { last } 1 \text { - } 2 \text { days. During the retreat there are } 1 \text { - } 2 \\
\text { bigger themes that students will work with. }\end{array}$ & $\begin{array}{l}\text { Isaacs, 1999; Nonaka } \\
\text { \& Takeuchi 1995; } \\
\text { Kolb, } 1984 .\end{array}$ \\
\hline $\begin{array}{l}\text { Learning café / } \\
\text { World Café }\end{array}$ & $\begin{array}{l}\text { The objectives are set either by the coach or by } \\
\text { students. Students will work in small groups and } \\
\text { every group may have its own sub-objective. One } \\
\text { student per group will act as a host and will stay } \\
\text { in the same group and others will visit to every } \\
\text { group for } 15 \text { - } 30 \text { minutes. The host presents the } \\
\text { results gained so far to new students. }\end{array}$ & $\begin{array}{l}\text { Commonly utilized } \\
\text { method, origin so far } \\
\text { unknown. }\end{array}$ \\
\hline $\begin{array}{l}\text { Competing } \\
\text { parallel groups }\end{array}$ & $\begin{array}{l}\text { Several small groups work with for the same object. } \\
\text { The results of a group are compared and discussed } \\
\text { together and challenged by other groups. }\end{array}$ & de Bono, 1970. \\
\hline $\begin{array}{l}\text { Learning } \\
\text { agreement }\end{array}$ & $\begin{array}{l}\text { Students practice how to set objectives for } \\
\text { themselves and to reflect their individual learning } \\
\text { experiences. }\end{array}$ & Partus methods. \\
\hline Theory & $\begin{array}{l}\text { Every student will read } 30 \text { - } 90 \text { books during their } \\
\text { studies. The books relate to for example ICT, } \\
\text { entrepreneurship, and personal development. New } \\
\text { insights are discussed on special "book trainings". }\end{array}$ & $\begin{array}{l}\text { Isaacs, 1999; Nonaka } \\
\text { \& Takeuchi 1995; } \\
\text { Kolb, } 1984 .\end{array}$ \\
\hline Quality check & $\begin{array}{l}\text { Yearly event for checking how processes such as } \\
\text { individual learning, communal learning and } \\
\text { measured of cooperative have developed. There } \\
\text { are three levels for each } 12 \text { process. Every level of } \\
\text { measures has to be passed every time to sustain } \\
\text { the achieved levels. }\end{array}$ & $\begin{array}{l}\text { Partus methods. } \\
\text { Modified for IT } \\
\text { Bachelor education by } \\
\text { coaches in SUAS. }\end{array}$ \\
\hline Cross fertilization & $\begin{array}{l}\text { Students visit to other cooperatives trainings and } \\
\text { other events. Learning experiences are later } \\
\text { shared to members of the own team. }\end{array}$ & $\begin{array}{l}\text { Concept from Partus } \\
\text { methods. The } \\
\text { principle has been } \\
\text { commonly utilized. }\end{array}$ \\
\hline Six Thinking hats & $\begin{array}{l}\text { Tools for innovation, usually used in problem } \\
\text { solving related to projects to get new insights. Six } \\
\text { thinking hats help learners to change their } \\
\text { viewpoint when searching for new ideas or } \\
\text { solving problematic situations. }\end{array}$ & de Bono, 1999. \\
\hline
\end{tabular}

Table 3. Examples of team learning methods utilized with the learning environment. 
In addition to the methods listed in table 3 development discussions are carried out with all of the students in the IT degree programme once per year.

\section{Evaluation of learning}

Practices for evaluating students' results and the learning process while achieving the results have been discussed and developed within all our study paths. We emphasize self evaluation and peer evaluation in parallel with teachers' or coaches' evaluation. Customer projects are also evaluated by customers. This practice is called 360 degree evaluation.

In some of the courses within the project learning path the conventional tests are used as well as instructors' evaluation of practical assignments. Our goal is to continuously learn from the evaluation, therefore the evaluation criteria and justifications for the evaluations are always open for discussion.

\section{Observations on current and future challenges}

\subsection{Examples of designed actions based on the analysis of the data}

After analyzing the data gathered by interviews, observations and analyzing documents in information repositories used by teampreneurs, suggestions were made to the coach of the first IT cooperative. Based on the suggestions for actions the coach has deployed designed actions with the teampreneurs. Here are some examples of the designed action put into practice:

- During the interviews the students of the game team expressed their interest in increasing cooperation with other student groups. The students of the game team were later invited to a two day retreat and they have been participating in the trainings of the second IT cooperative

- Challenges in leadership and feeling of ongoing "rush" expressed by teampreneurs was discussed and analyzed together with the coach of the first IT cooperative. Based on the analysis of the situation the coach took the topics leadership of the team, and teampreneurs feeling of rush and where it comes from to the next training for discussion

- The bias towards internal development projects and avoiding customer visits was analyzed with the coach of the first IT cooperative. Based on the analysis teampreneurs were challenged to visit a certain amount of potential customers within the next two weeks to get new and versatile projects that would help them to achieve their learning objectives.

- The lack of leadership within the first IT cooperative has been discussed for several times. The issue has been recognized and actions based on it are currently in process.

\subsection{Challenges related to students and their learning}

Based on gathered data - mostly observation and reading documents from information repository - it seems that some of the students have chosen their study path for reasons that we were not able to predict. It seems that in those cases students have selected "the easiest way" to get a degree. One possible explanation that relates to any student in any university is a suggestion that whenever students are able to decide whether they put extra effort to some issue or not, they will not. Based on the author's experience as being a lecturer this 
suggestion seems to be valid, at least to some extent. In practice this means that from the student's point of view they avoid any tasks in which they will not be rewarded with ECTS units or money.

Another challenge emerged mostly with IT entrepreneurs is the lack of commitment. Teampreneurs have had quite a vast scope of freedom while agreeing on the rules of conduct and working approach. They have so far preferred to have great freedom but most of the students are not familiar with taking responsibility for their own or with teams work. Based on tens of observations they have violated the basic rules of conduct that they have mutually agreed, such as keeping a deadline for a teams' joint task like visiting potential customers or reading a book.

Based on these findings one possible explanation of teampreneurs' challenges is that unlearning from the working approach of traditional school where teachers will tell students what to do, seems to be difficult and time consuming. An alternative explanation is that students just want to "chill out" (as described above) if no one requires anything more from them. Based on the interviews and observations conducted with the first IT cooperative, there was a severe lack of leadership within the team. Rules that the teampreneurs have mutually agreed on have been repeatedly violated without any consequences and promises have been given but not kept, over and over again.

To summarize, the teampreneurs don't have enough experience and therefore lack of courage to deal with crisis situations; they rather tend to avoid them. In those situations where teampreneurs lack leadership or courage to face difficult or unpleasant situations, the role of the coach is crucial. When difficult issues are continuously avoided by the teampreneurs, it will be the coach' unpleasant task to take the dialogue back to the track and take care that the teampreneurs will not avoid of solving the issues that prevent them from developing as a team. When the teampreneurs will get more experienced and by that means find the courage to solve their challenges independently the coach can step aside again.

\subsection{Challenges related to personnel and their learning}

A challenge we have to bear in mind all the time is related to the way how students and colleagues within the IT degree programme value themselves as members of the community of practice.

In the course of development of the learning environment the curriculum for IT bachelor degree has gone through remarkable changes. In the beginning of this radical change process it was noticed that among students and also among colleagues there emerged lot of tensions and not all of the tensions were positive. These tensions could partly be described as normal resistance to change. Another very important element of any change process is adequate communication between all parties involved. In the beginning of the change process the importance of communication was probably not fully realized or its role in the change process was underestimated.

When listening to coffee room and other unofficial discussions at the starting phase of the change process, it soon became evident that some students who were not interested in studying as ICT entrepreneurs or were not interested studying within an international team 
learning path had sometimes felt themselves "leftovers". The same kind of atmosphere was in the beginning recognized also among personnel of the IT degree programme. It took several months, required many discussions and also some arguing before a common view on the way to go on forward with the changes and how to communicate about them was agreed.

Because any change always means destroying something that has existed before, it is essential that the current situation and those involved in constructing it are valued in a polite manner. Through ongoing dialogue with colleagues we have been able to see the change as a possibility to develop something new instead of only rejecting or destroying existing structures for learning.

\subsection{Minor success stories during the way}

For already two years we have been learning to have dialogue with all the colleagues within the IT degree programme. In the beginning these meetings were more or less discussions and not always even polite at all. Individuals acted with "skilled incompetence" trying to remain in unilateral control of situations and to avoid feeling vulnerable (Argyris and Schön 1996, 90). After two years and tens of continuous weekly dialogues with colleagues the situation started to change little by little. Based on these changes in communication with colleagues it seems that we are already beginning to have some kind of shared vision of what we want to achieve together with the new learning environment for IT Bachelor education.

Another observation that could be described as a minor success story is related to students who study in international team learning path. Those who have 120 ECTS credits may study for Double Degree during their third academic year. This requirement seems to work as a stick and the Double Degree as a carrot for those who want to study abroad.

Students within all three study paths have been satisfied with learning in projects. We have also got lot of positive feedback about the increased flexibility in studies and practiceorientation of the content that has been offered for IT Bachelor students. Partly based on the positive feedback from students several colleagues have found more courage to explore and apply new methods of learning in IT Bachelor education.

Most colleagues within the IT degree programme have been involved in the development project called TULKKI where a cooperation model between Saimaa University of Applied Sciences and other organizations in South Eastern Finland has been developed. The cooperation model complements the learning environment that has been developed by clarifying each parties' (student, teacher, company representative) role in acquiring new projects and steering them. The development project has also provided possibilities to explore and implement new team learning methods into practice simultaneously with the development of the learning environment.

\section{Discussion}

It has been interesting to observe how individuals act in a learning environment where they have much freedom to choose how they learn and in some extent also what to learn. So far most of the data supports the finding that students feel more motivated when they have 
more possibilities and freedom to choose. However, they have not so far much grasped these possibilities but rather enjoyed the freedom to study in their own rhythm. This interpretation was supported when reviewing the students' transcription of records. Students tend to study issues that they prefer and postpone the issues they feel challenging or even boring. From this point of view students are similar regardless of the study path they have chosen.

The issue that was widely expressed during interviews and later also validated through observations was that teampreneurs tend to discuss and plan but they will not act. The hardest part is always the path from idea to innovation, in other words how to put ideas and decisions into practice. Learning by doing requires practice on the individual level and shared practice in team level. Without these crucial elements there will be no basis for team learning. When there are not enough versatile projects available, there will not be enough versatile learning guaranteeing that studies will progress in an appropriate way.

\begin{tabular}{|l|l|}
\hline An objective & Solutions in our learning environment \\
\hline $\begin{array}{l}\text { Student's own activity is } \\
\text { emphasized. }\end{array}$ & $\begin{array}{l}\text { The methods are used within the learning environment } \\
\text { make a student an active subject rather than passive } \\
\text { object. }\end{array}$ \\
\hline $\begin{array}{l}\text { Learning is carried out also in } \\
\text { simulated or real-life situations. }\end{array}$ & $\begin{array}{l}\text { In every study path project learning is utilized in real } \\
\text { customer projects with cooperation organizations. } \\
\text { Currently there are over thirty parallel projects where } \\
\text { our IT students are learning with the support of teachers } \\
\text { and representatives of the customer organizations. }\end{array}$ \\
\hline $\begin{array}{l}\text { Students have a possibility to } \\
\text { interact with real } \\
\text { entrepreneurship. }\end{array}$ & $\begin{array}{l}\text { Within the ICT entrepreneurship study path students } \\
\text { study as teampreneurs for three years. }\end{array}$ \\
\hline $\begin{array}{l}\text { Learning is based on problem } \\
\text { solving and interaction. }\end{array}$ & $\begin{array}{l}\text { Team learning is emphasized within all three study } \\
\text { paths. Problem based learning is commonly used in } \\
\text { courses and customer projects. }\end{array}$ \\
\hline $\begin{array}{l}\text { Learners are supported by } \\
\text { network of specialists. }\end{array}$ & $\begin{array}{l}\text { Information sharing between all colleagues in the IT } \\
\text { degree programme about progress of learning objectives } \\
\text { of students is ongoing. Dialogues 2-4 hours per week } \\
\text { with colleagues will guarantee that the learners are } \\
\text { supported with their learning objectives. }\end{array}$ \\
\hline $\begin{array}{l}\text { The teachers' role develops from } \\
\text { delivering information to } \\
\text { organizer, tutor, supervisor and } \\
\text { developer of the learning } \\
\text { environment. }\end{array}$ & $\begin{array}{l}\text { Teachers act on several roles, such as lecturers, project } \\
\text { steering group members, supervisors, specialists, } \\
\text { facilitators, and coaches. Teachers are also responsible for } \\
\text { development of the learning environment and exploring } \\
\text { and applying new methods and instruments for learning. }\end{array}$ \\
\hline
\end{tabular}

Table 4. Summary of objectives for learning environment and our solutions for achieving them.

Students who have decided to study in English within the international team learning study path have committed themselves to study at least 120 ECTS credits during their first two academic years. The limit was originally set to guarantee that the students who will go abroad for a year will not drop out during their studies. Based on experiences so far, the 
limit has been "an accidental carrot" and it has had a strong positive effect to the students' motivation for studies overall. Based on the observations with three international groups it seems that students will learn a language and do a project work on a practical level. It requires a few weeks to "defrost" after which students will work with projects in international teams more fluently.

A short summary of the objectives set for a learning environment that will support entrepreneurship set by the Ministry of Education and Culture and examples of how they have been solved in our learning environment are presented in table 4.

\section{Summary}

The trajectory for building the learning environment for the IT Bachelor education at Saimaa University of Applied Sciences described in this article started three years ago. Some changes in personnel and increased dialogue and cooperation between colleagues laid the cornerstones for the radical change process in developing the learning environment for IT Bachelor education in Saimaa University of Applied Sciences.

These changes had not happened without individuals who had enough courage to work with uncertainty and unknown. By slowly increased mutual trust between colleagues involved in the development of the learning environment there have been enough strength and stamina to overcome resistance and even moments of despair. Realization of transformational change in education is not an easy task but based on the analysis so far it can be achieved. At the same time the objectives for a learning environment that supports entrepreneurship in the way set by the Ministry of Education and Culture have been achieved.

When the study started in February 2010, there was one IT cooperative and a small group of international students. Now, in October 2011, there are already two IT cooperatives, the third international group (19 students) and the amount of Double Degree students is steadily increasing. The Double Degree cooperation has awaken an interest for other partner Universities in Europe as a result of which two new double degree agreements are currently in process. There is also been some more students who are interested in studying by developing games, a fact that could lead to establishment of another game team. Based on the facts above and the interest that the learning environment has created on national level it seems that the learning environment we have created might somehow meet the challenges that we nowadays face in the IT Bachelor education in Finland.

Unfortunately it seems that our degree program will run out of time. On 5th of October 2011 we got the breaking news from the Ministry of Education and Culture, a suggestion of discontinuation of our degree programme. If this will happen, the results achieved with the learning environment described in this article will come too late. In spite of this, it has been a very interesting and challenging time to participate in the creation of the learning environment. Who knows if the learning environment described in the article could be implemented somewhere else with people with the same kinds of courage and leading thoughts that we have in the IT degree program of Saimaa University of Applied Sciences. 


\section{Acknowledgements}

Studying the IT students utilizing team learning methods and describing the learning environment that has been built in cooperation with colleagues has been an interesting and challenging task. It has given the author a possibility to investigate theoretical background of several disciplines and to interview and observe students who have been studying within the learning environment.

The author wants to thank all the colleagues in the IT degree programme for the cooperation and especially all the students who have been studying within the learning environment that we have created together. When you have done your best, there is no need for further explanations.

\section{References}

Argyris, C. and Schön, D. (1996) Organizational learning II: Theory, method and practice, Reading, Mass: Addison Wesley.

Belbin, R. Meredith (2003). Team Roles at Work. Elsewier.

Brown, J. \& Duguid, P. (1991). Organizational Learning and Communities of Practice; Toward a Unified view of Working, Learning and Innovation. Organization Science, Vol. 2, No. 1, February 1991.

Commission of the European Communities. Brussels, 10.11.2005. COM(2005)548 final. 2005/0221(COD). Proposal for a Recommendation of the European Parliament and of the Council on key competences for lifelong learning.

Corbin, J. \& Strauss A. (2008) Basics of Qualitative Research 3e. Techniques and Procedures for Developing Grounded Theory. Sage Publications.

de Bono, E. (1970). Lateral thinking. Penguin books.

de Bono, E. (1999). Six Thinking Hats, New York: Back Bay Books

Denzin, N.K. \& Lincoln, Y.S. (editors). Collecting and Interpreting Qualitative Materials. Sage Publications 2003.

Dixon, N. (1994). The Organizational Learning Cycle, how we can learn collectively. London: McGraw-Hill.

Easterby-Smith, M., Burgoyne, J. \& Araujo, L. (eds) Organizational Learning and the Learning Organization. Sage Publications 1999.

Eisenhardt, K.M. Building theories from Case Study Research, Academy of Management Review, 1989 14(4), p. 532-550.

Eisenhardt K. \& Graebner M.(2007). Building theories from case study research. Academy of Management, 50 (1), 25-32.

Ministry of Education (2008). Koulutus ja tutkimus 2007 - 2112 kehittämissuunnitelma. Opetusministeriö.

Flick, U. (2009). An Introduction to Qualitative Research, Edition 4. Sage Publications.

Isaacs, W. (1999). Dialogue: The art of thinking together. Doubleday, Randomhouse Inc.

Herr, K. \& Anderson, G. (2005) The Action Research Dissertation: A guide for students and faculty. Sage Publications 2005.

Juvonen, P \& Ovaska, P. (2010). Studying IT Team Entrepreneurship as a Potential Learning Organization. Published in Knowledge Management and Information Sharing (KMIS2010) conference in Valencia 25. - 28.10.2010.

Kolb, David (1984) Experimental Learning. Prentice-Hall, Englewood Cliffs, NJ. 
Lave, J. \& Wenger, E. (1991) Situated Learning: Legitimate Peripheral Participation. Cambridge University Press 1991.

Lipman-Blumen, Jean \& Leavitt, Harold (1999). Hot Groups. Seeding them, Feeding Them, and Using Them to Ignite Your Organization. Oxford University Press.

Marquardt, Micheal J. (2002). Building the Learning organization. Mastering the 5 elements of Corporate Learning. Nicholas Breadley Publishing.

Marquardt, Micheal J. (2009). Optimizing the power of Action Learning. Solving problems and Building Leaders in Real Time. Davies-Black.

Ministry of Education (2004). Policy for entrepreneurship education. Opetusministeriön julkaisuja 2004:18.

Ministry of Education (2008). Koulutus ja tutkimus 2007 - 2112 kehittämissuunnitelma. Opetusministeriön julkaisuja 2008:9.

Ministry of education (2009). Yrittäjyyskasvatuksen suuntaviivat. Opetusministeriön julkaisuja 2009:7.

Nonaka, Ikujiro (1994). A dynamic theory of Organizational Knowledge Creation. Organization Science, Vol. 5 No. 1, pp. 14 - 37.

Nonaka, Ikujiro \& Takeuchi, Hirotaka (1995) The Knowledge Creating Company. How Japanese Companies Create the Dynamics of Innovation. Oxford University Press.

Nonaka, I. \& Toyama, R. (2003) The knowledge-creation theory revisited: knowledge creation as a synthesizing process. Knowledge Management Research \& Practice, Vol. 1 Issue 1, pp. 2-10.

Partus methods, available in http:/ / partus.fi/partusoy/partus-english , referred 30.5.2011

Senge, P. (1990). The Fifth Discipline - The Art \& Practice of the Learning Organization, Sage, New York.

Senge, Peter, M. (2006). The Fifth Discipline Revised and Updated, Random house 2006.

Senge, P., Ross, R., Smith B., Roberts, C. \& Kleiner, A. (1994). The Fifth Discipline Fieldbook. Nicholas Brealey publishing. Strategies and Tool for Building a Learning Organization.

Senge, P., Kleiner, A., Roberts, C., Roth, G. \& Smith, B. (1999) The Dance of Change. A Fifth Discipline Fieldbook for Mastering the Challenge of Learning Organizations.

Senge, P., Cambron-McCabe, N., Lucas, T. Smith, B., Dutton, J. \& Kleiner, A. (2000). A Fifth discipline resource. Schools that learn.

Smeds, Riitta, Krokfors, Leena, Ruokamo, Heli \& Staffans, Aija (2010). Aalto-yliopiston teknillinen korkeakoulu Informaatio- ja luonnontieteiden tiedekunta, Tuotantotalouden laitos, Yritystoiminnan simulointilaboratorio SimLab.

Strauss, A. \& Corbin, J. Basics of Qualitative Research, Techniques and Procedures for Developing Grounded Theory, second edition. Sage Publications 1990.

Stringer, E.T. (2007) Action Reseacrh third edition. Sage publications.

Symon, G. \& Cassell, C. (Eds.) (1998) Qualitative methods and analysis in organizational research. A practical guide. Sage Publications.

Von Krogh, Georg, Ichijo, Kazuo \& Nonaka, Ikujiro (2000). Enabling Knowledge Creation. How to Unlock the Mystery of Tacit Knowledge and Release the Power of Innovation. Oxford University Press.

Wenger, Etienne (1998) Communities of Practice. Learning, meaning and Identity. Cambridge University Press 1998.

Yin, R.K. Case Study Research Design and methods, Sage Publications 1994.

Yin, R. K. (2003) Applications of Case Study Research. Thousand Oaks: Sage Publications. 


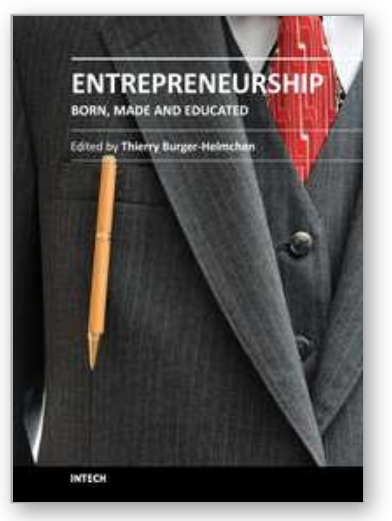

\author{
Entrepreneurship - Born, Made and Educated \\ Edited by Prof. Thierry Burger-Helmchen
}

ISBN 978-953-51-0210-6

Hard cover, 336 pages

Publisher InTech

Published online 14, March, 2012

Published in print edition March, 2012

Entrepreneurship has a tremendous impact on the economic development of a country. As can be expected, many public policies foster the development of self- entrepreneurship in times of unemployment, praise the creation of firms and con- sider the willingness to start new ventures as a sign of good fortune. Are those behaviours inherent to a human being, to his genetic code, his psychology or can students, younger children or even adults be taught to become entrepreneurs? What should be the position of universities, of policy makers and how much does it matter for a country? This book presents several articles, following different research approaches to answer those difficult questions. The researchers explore in particular the psychology of entrepreneurship, the role of academia and the macroeconomic impact of entrepreneurship.

\title{
How to reference
}

In order to correctly reference this scholarly work, feel free to copy and paste the following:

Pasi Juvonen (2012). Fostering Entrepreneurship by Developing a New Learning Environment Within a Finnish University of Applied Sciences, Entrepreneurship - Born, Made and Educated, Prof. Thierry Burger-Helmchen (Ed.), ISBN: 978-953-51-0210-6, InTech, Available from: http://www.intechopen.com/books/entrepreneurshipborn-made-and-educated/fostering-entrepreneurship-by-developing-a-new-learning-environment-within-afinnish-university-of-a

\section{INTECH}

open science | open minds

\author{
InTech Europe \\ University Campus STeP Ri \\ Slavka Krautzeka 83/A \\ 51000 Rijeka, Croatia \\ Phone: +385 (51) 770447 \\ Fax: +385 (51) 686166 \\ www.intechopen.com
}

\author{
InTech China \\ Unit 405, Office Block, Hotel Equatorial Shanghai \\ No.65, Yan An Road (West), Shanghai, 200040, China \\ 中国上海市延安西路65号上海国际贵都大饭店办公楼 405 单元 \\ Phone: +86-21-62489820 \\ Fax: +86-21-62489821
}


(C) 2012 The Author(s). Licensee IntechOpen. This is an open access article distributed under the terms of the Creative Commons Attribution 3.0 License, which permits unrestricted use, distribution, and reproduction in any medium, provided the original work is properly cited. 